\title{
Pengaruh Keterampilan Mengajar dan Motivasi Kerja terhadap Kinerja Guru
}

\author{
Elta Chrisvianty ${ }^{1}$, Yasir Arafat $^{2}$, Mulyadi $^{3}$ \\ ${ }^{1}$ SMP Negeri 3 Prabumulih, ${ }^{2,3}$ Universitas PGRI Palembang \\ 1eltaputri8@gmail.com, ${ }^{2}$ yasir_arafat14@yahoo.com, ${ }^{3}$ mulyadi.aliusman@yahoo.com
}

\begin{abstract}
Abstrak
Penelitian ini bertujuan untuk mengetahui ada tidaknya pengaruh keterampilan mengajar dan Motivasi Kerja secara parsial maupun secara bersama-sama terhadap kinerja guru di SMP Negeri 3 Prabumulih. Penelitian ini menggunakan metode kuantitatif dengan pendekatan korelasional (sebab akibat). Data dianalisis menggunakan regresi linear berganda korelasi parsial dan korelasi ganda. Penelitian ini menghasilan kesimpulan 1) Ada pengaruh keterampilan mengajar terhadap Kinerja Guru, artinya keterampilan mengajar guru dapat mempengaruhi Kinerja Guru. Besarnya pengaruh keterampilan mengajar terhadap Kinerja Guru adalah 37,3\%; 2) Ada pengaruh motivasi kerja guru terhadap Kinerja Guru, artinya motivasi kerja dapat mempengaruhi Kinerja Guru. Besarnya pengaruh supervisi akademik terhadap Kinerja Guru adalah 38,0\%; dan 3) Ada pengaruh keterampilan mengajar dan motivasi kerja secara bersama-sama terhadap Kinerja Guru. Dengan demikian keterampilan mengajar dan motivasi kerja dapat mempengaruhi Kinerja Guru. Keterampilan mengajar dan motivasi kerja mampu mempengaruhi Kinerja Guru dengan kontribusi $51,2 \%$ sedangkan sisanya $48,8 \%$ dijelaskan oleh faktor-faktor yang tidak termasuk dalam penelitian ini.
\end{abstract}

Kata Kunci: Keterampilan Mengajar, Motivasi Kerja, Kinerja Guru

\begin{abstract}
This study aims to determine whether there is an effect of teaching skills and work motivation partially or collectively on the performance of teachers at SMP Negeri 3 Prabumulih. This study uses a quantitative method with a correlational approach (cause and effect). Data were analyzed using multiple linear regression with partial correlation and multiple correlation. This study resulted in the conclusion 1) There is an effect of teaching skills on teacher performance, meaning that teacher teaching skills can affect teacher performance. The magnitude of the influence of teaching skills on teacher performance is $37.3 \%$; 2) There is an effect of teacher work motivation on teacher performance, meaning that work motivation can affect teacher performance. The magnitude of the influence of academic supervision on teacher performance is $38.0 \%$; and 3 ) There is an effect of teaching skills and work motivation together on teacher performance. Thus teaching skills and work motivation can affect teacher performance. Teaching skills and work motivation are able to influence teacher performance with a contribution of $51.2 \%$ while the remaining $48.8 \%$ is explained by factors that are not included in this study.
\end{abstract}

Keywords: Teaching Skills, Work Motivation, Teacher Performance

\section{PENDAHULUAN}

Pendidikan pada umumnya adalah usaha membina dan mengembangkan pribadi manusia dalam aspek rohani dan jasmani, juga harus berlangsung secara bertahap (Arifin, 2012). Menurut Arifin (2012), pendidikan adalah suatu proses pembentukan kemampuan dasar, baik menyangkut daya pikir (intelektual) maupun daya perasaan (emosional), menuju ke arah tabiat manusia dan manusia biasa. Sedangkan menurut Putra (2013) menyatakan bahwa pendidikan adalah aktivitas dan usaha manusia untuk meningkatkan kepribadiannya dengan jalan membina potensi-potensi pribadinya, yaitu rohani (pikir, karsa, ras, cipta dan 
budi nurani) dan jasmani (panca indra serta keterampilan-keterampilan). Oleh karena itu, sesuatu yang yang bertitik akhir kepada optimalisasi perkembangan, baru dapat tercapai bila mana berlangsung melalui proses demi proses pendidikan. Karena tidak ada satupun manusia yang dapat mencapai kesempurnaan hidup tanpa berlangsung melalui suatu proses pendidikan (Kristiawan, 2015; Kristiawan, 2016; Kristiawan dkk, 2017; Kristiawan dkk, 2019).

Inti dari proses pendidikan secara formal adalah mengajar. Sedangkan inti dari proses pembelajaran adalah mengoptimalkan proses belajar siswa, Karena pembelajaran merupakan suatu kegiatan yang melibatkan seseorang dalam upaya memperoleh pengetahuan, keterampilan dan nilai-nilai positif yang memanfaatkan sebagai sumber untuk belajar. Pembelajaran dapat melibatkan dua pihak, yaitu peserta didik sebagai pembelajar dan guru sebagai fasilitator, yang terpenting dalam kegiatan pembelajaran tersebut yaitu terjadinya proses pembelajaran (Budiman, 2016). Karena proses pembelajaran merupakan inti dari pengoptimalan proses belajar siswa. Oleh karena itu, dalam proses belajar mengajar akan selalu bertumpu pada persoalan bagaimana guru memberi suatu pembelajaran kepada siswa agar terjadi proses belajar yang optimal sehingga mampu mencapai tujuan yang diharapkan. Hal ini mendorong bahwa seorang guru harus mampu melaksanakan proses belajar mengajar secara professional dan efektif.

Seorang guru profesional harus menguasai betul seluk beluk pendidikan dan pengajaran serta ilmu-ilmu lainnya (Hamalik, 2015). Untuk melaksanakan profesinya tersebut, maka tenaga pendidik khususnya yang dimaksudkan dalam hal ini guru sangat memerlukan aneka ragam pengetahuan (Syah, 2012; Kristiawan dan Rahmat, 2018; Kristiawan dkk, 2018; Fitria dkk, 2019). Pengetahuan, keterampilan, dan kemampuan profesional ini harus selalu ditingkatkan terutama dalam menyiapkan sumber daya manusia yang mampu menghadapi persaingan dunia ditahun-tahun yang akan mendatang nanti. Dikatakan bahwa skill atau keterampilan guru juga perlu untuk ditingkatkan lagi karena guru mempunyai arti penting didalam pendidikan. Arti penting tersebut bertolak dari tugas dan tanggung jawab guru yang cukup berat untuk mencerdaskan peserta didiknya (Djamarah dan Zain, 2010).

Sejalan dengan tantangan kehidupan global, peran dan tanggung jawab guru pada masa mendatang akan semakin kompleks, sehingga menuntut guru untuk senantiasa melakukan berbagai peningkatan dan penyesuaian kemampuan profesionalnya. Guru harus lebih kreatif dalam mengembangkan proses pembelajaran peserta didik. Untuk menghadapi tantangan profesionalitas tersebut, guru perlu melakukan pembaruan ilmu dan pengetahuan yang dimilikinya secara terus menerus.

Seorang guru profesional juga dituntut untuk dapat melengkapi dirinya dengan berbagai keterampilan yang diharapkan dapat membantu dalam menjalankan tugasnya. Keterampilan dasar mengajar adalah keterampilan yang mutlak harus dipunyai seorang guru. Dengan pemilikan keterampilan dasar mengajar ini maka diharapkan guru dapat mengoptimalkan peranannya di dalam kelas (Djamarah dan Zain, 2010; Khasanah dkk, 2019; Turmini dkk, 2020; Resnawati dkk, 2020).

Sebagaimana diketahui bahwa ada beberapa keterampilan dasar, yaitu keterampilan membuka dan menutup pelajaran, keterampilan menjelaskan, keterampilan bertanya, keterampilan memberi penguatan, keterampilan membimbing diskusi kelompok kecil, keterampilan mengelola kelas, keterampilan mengadakan variasi, keterampilan mengajar perorangan dan kelompok kecil (Moedjiono, 2014). Bila guru tidak menggunakan keterampilan dalam pembelajaran, maka akan membuat siswa merasa cepat bosan, faktor yang sering menjadi pengganggu dalam proses belajar mengajar di sekolah adalah faktor kebosanan siswa. Dalam proses belajar mengajar tiap siswa mempunyai perhatian, minat dan motivasi yang berbeda. Pada satu saat siswa mempunyai motivasi yang rendah, tetapi pada saat lain siswa memiliki motivasi yang tinggi, ada yang sebagian siswa belajar dan ada yang tidak ikut belajar melainkan berbincang-bincang mengenai hal-hal yang terlepas dari pelajaran. Hal ini disebabkan oleh adanya penyajian kegiatan belajar yang begitu-begitu 
saja yang akan mengakibatkan perhatian, motivasi dan minat siswa terhadap guru dan sekolah akan menurun.

Berdasarkan hasil pengamatan atau hasil observasi yang penulis lakukan di SMP Negeri 3 Prabumulih, guru sudah cukup baik namun masih ada beberapa guru yang belum melakukan kegiatan pembelajaran berdasarkan indikator keterampilan mengajar. Indikator tersebut adalah keterampilan membuka dan menutup pelajaran, keterampilan menjelaskan, keterampilan bertanya, keterampilan memberi penguatan, keterampilan membimbing diskusi kelompok kecil, keterampilan mengelola kelas, keterampilan mengadakan variasi, keterampilan mengajar perorangan dan kelompok kecil.

Untuk indikator keterampilan membuka dan menutup pelajaran, masih ada guru yang belum melakukan menutup pelajaran. Alasannya karena keterabatasan waktu, guru hanya memperhatikan waktu penyampaian materi saja sehingga pada akhir pembelajaran guru tidak menutup pelajaran. Pada indikator keterampilan menjelaskan masih ada guru yang menjelaskan pembelajaran dengan menggunakan buku paket saja, seharusnya guru menjelaskan pembelajaran berdasarkan Rencana Pelaksanaan Pembelajaran Harian (RPPH) yang telah disusun sebelum mengajar. Akibatnya materi yang disampaikan tidak berdasarkan indikator keberhasilan belajar.

Demikian pula dengan keterampilan bertanya, masih ada guru yang tidak bertanya kepada siswanya setelah menjelaskan materi. Akibatnya banyak siswa yang belum mengerti tentang materi yang disampaikan. Selanjutnya keterampilan memberi penguatan, masih ada guru yang tidak menyimpulkan materi diakhir pembelajaran. Hal ini berakibat masih ada siswa yang masih bingung tentang materi yang baru disampaikan guru tersebut. Untuk keterampilan membimbing diskusi kelompok kecil, masih ada guru yang belum melakukannya. Guru hanya duduk di depan kelas, sehingga guru tidak mengetahui apa saja yang menjadi kendala siswa dalam memahami materi secara berkelompok.

Pada indikator keterampilan mengelola kelas, guru sudah melakukannya sehingga keterampilan mengelola kelas sudah berjalan dengan baik. Selanjutnya indikator keterampilan mengadakan variasi, masih banyak guru yang belum melakukannya. Guru hanya menggunakan metode ceramah saat penyampaian materi, sehingga siswa terlihat bosan dalam belajar. Dan terakhir adalah indikator keterampilan mengajar perorangan dan kelompok kecil. Pada indikator ini, masih ada guru yang belum melakukannya, hal ini disebabkan guru hanya bisa mengajar pada klasikal dan kelompok besar.

Selain keterampilan mengajar, motivasi juga dapat mempengaruhi kinerja guru. Uno (2013), motivasi kerja guru tidak lain adalah suatu proses yang dilakukan untuk menggerakkan guru agar perilaku mereka dapat diarahkan pada upaya-upaya yang nyata untuk mencapai tujuan yang telah ditetapkan. Motivasi kerja guru adalah suatu hal yang dibutuhkan guru untuk menggerakkan dan mengarahkan guru dalam melakukan pekerjaan guna mencapai tujuan yang telah ditetapkan. Guru akan bergerak mengerjakan pekerjaan apabila ada yang memotivasi baik dari dalam diri maupun dari luar.

Berdasarkan hasil pengamatan peneliti, motivasi guru di SMP Negeri 3 Prabumulih dalam hal pengembangan diri masih kurang optimal. Di lapangan masih terdapat beberapa guru yang masih belum menguasai komputer, masih mengalami kesulitan membuat media pembelajaran. Sebagian guru masih belum optimal dalam mengembangkan profesionalitas, meng-up date pengetahuan yang dimliki. Hal ini dapat dilihat masih sedikitnya guru di Kabupaten Purworejo yang membuat karya ilmiah, melakukan penelitian pendidikan dan dalam membuat alat peraga yang kreatif. Pengembangan potensi guru harus lebih ditingkatkan agar dapat meningkatkan prestasi kerja sehingga dapat menghasilkan output yang berkualitas.

\section{METODE PENELITIAN}

Penelitian ini merupakan penelitian kuantitatif dengan pendekatan korelasional (sebab-akibat). Penelitian berjenis korelasional bertujuan untuk mengetahui adanya hubungan sebab-akibat yang saling mempengaruhi dan berhubungan antar variabel penelitian. Penelitian ini terdiri dari tiga variabel, yaitu dua variabel bebas dan satu variabel 
terikat. Variabel bebas pada penelitian ini berupa keterampilan mengajar $\left(X_{1}\right)$ dan motivasi kerja $\left(\mathrm{X}_{2}\right)$, sedangkan variabel terikat pada penelitian ini adalah kinerja guru $(\mathrm{Y})$. Populasi dalam penelitian ini adalah seluruh guru SMP Negeri 3 Kota Prabumulih yang berjumlah 82 orang dengan jumlah sampel diambil sebayak 45 guru yang diambil menggunakan rumus Slovin.

Kinerja guru adalah suatu kondisi yang menunjukkan kemampuan seorang guru dalam menjalankan tugasnya di sekolah serta menggambarkan adanya suatu perbuatan yang ditampilkan guru selama melakukan aktivitas pembelajaran. Kinerja guru diukur dengan tiga indikator, yaitu 1) Perencanaan program kegiatan pembelajaran, 2) Pelaksanaan kegiatan pembelajaran, dan 3) Evaluasi pembelajaran.

Keterampilan mengajar adalah kemampuan guru dalam menyajikan materi pelajaran seperti penguasaan materi pelajaran, penggunaan media pembelajaran, dan memilih metode yang tepat. Keterampilan mengajar diukur dengan delapan indikator, yaitu keterampilan membuka dan menutup pelajaran, keterampilan menjelaskan, keterampilan bertanya, keterampilan memberi penguatan, keterampilan membimbing diskusi kelompok kecil, keterampilan mengelola kelas, keterampilan mengadakan variasi, keterampilan mengajar perorangan dan kelompok kecil.

Motivasi kerja adalah dorongan bagi seorang guru untuk menggerakkan dan mengarahkan guru melakukan pekerjaan sesuai dengan rencana guna mencapai tujuan yang telah ditetapkan. Motivasi kerja diukur dengan dua indikator, yaitu 1) motivasi internal, dan 2) motivasi eksternal (Andriani dkk, 2018; Renata dkk, 2018; Salwa dkk, 2019).

\section{HASIL PENELITIAN DAN PEMBAHASAN \\ Pengaruh Keterampilan Mengajar Guru terhadap Kinerja Guru}

Dari hasil penelitian memperlihatkan bahwa keterampilan mengajar berpegaruh signifikan terhadap Kinerja Guru. Hasil ini mendukung hipotesis yang diajukan di mana keterampilan mengajar guru berpengaruh terhadap Kinerja Guru. Menurut hasil perhitungan berdasarkan persamaan regresi, dapat dijelaskan bahwa jika nilai keterampilan mengajar guru $\left(X_{1}\right)$ meningkat 1 unit skor, maka Kinerja Guru $(Y)$ akan meningkat sebesar 0,373, dengan ketentuan nilai motivasi kerja adalah 0 . Mengenai ada tidaknya pengaruh yang signifikan antara keterampilan mengajar $\left(\mathrm{X}_{1}\right)$ terhadap Kinerja Guru $(\mathrm{Y})$ dapat dilihat pada besarnya nilai yang terdapat pada Tabel 4.9. Nilai $t_{\text {hitung }}$ keterampilan mengajar sebesar 2,621 dengan signifikan sebesar $0,012(p<0,05)$ dengan $t_{\text {tabel }}$ sebesar 1,68023 atau dengan kata lain $t_{\text {hitung }}>t_{\text {tabel }}$, maka menolak Ho dan menerima Ha atau dengan kata lain ada pengaruh yang signifikan keterampilan mengajar $\left(\mathrm{X}_{1}\right)$ terhadap Kinerja Guru $(\mathrm{Y})$.

Hasil penelitian ini sejalan dengan temuan Husain (2012) menunjukkan bahwa penerapan keterampilan mengajar belum maksimal yang dilakukan oleh guru Pendidikan agama Islam pada SMP Negeri di Kecamatan Tubbi Taramanu Kabupaten polman. Faktor pendukung adalah motivasi kepala sekolah, buku-buku paket dan guru aktif dalam kegiatan Musyawarah Guru mata Pelajaran (MGMP). Faktor penghambat adalah belum tersedianya sarana dan fasilitas pembelajaran yang memadai, kurangnya minat peserta didik dalam mengikuti proses pembelajaran pendidikan agama Islam, kompetensi guru masih kurang, masih banyak peserta didik yang belum bisa mengaji dan kurang lancar serta kurangnya pelatihan guru pendidikan agama Islam. Solusi yang dilakukan dalam mengatasi hambatan dalam penerapan keterampilan mengajar guru pendidikan agama Islam adalah berusaha membenahi dan mencari alternatif yang terbaik dalam menyelesaikan berbagai masalah dalam proses pembelajaran.

Adapun hasil dari proses penerapan keterampilan mengajar guru pendidikan agama Islam dalam meningkatkan prestasi belajar peserta didik pada SMP Negeri di Kecamatan Tubbi Taramanu Kabupaten polman penulis belum menemukan hasil yang maksimal, hal ini dapat dilihat dari kurang meningkatnya ilmu pengetahuan, sikap dan nilai kurang dalam hal pengamalan nilai-nilai agama dalam kehidupan sehari-hari, hal ini juga dapat diukur dari 
hasil perolehan nilai peserta didik yang memperoleh nilai kategori di bawah rata-rata kriteria ketuntasan minimal (KKM) setelah melalui tes/evaluasi semester.

Habibie (2017) dengan judul "Analisis Keterampilan Dasar Mengajar Guru Kimia Yang Mengikuti MGMP MIPA di MAN Kota Tegal". Tujuan penelitian ini adalah untuk mengetahui keterampilan dasar mengajar guru kimia yang mengikuti MGMP MIPA di MAN Kota Tegal. Data penelitian diperoleh melalui lembar obeservasi, wawancara, dan dokumentasi. Hasil penelitian di MAN Kota Tegal tentang keterampilan dasar mengajar guru kimia yang mengikuti MGMP MIPA menunjukkan bahwa prosentase skor rata-rata dalam ketiga keterampilan dasar mengajar (keterampilan membuka dan menutup, keterampilan bertanya, dan keterampilan mengadakan variasi) sebesar $54 \%$ dengan kategori kurang sekali. Keterampilan yang dinilai yaitu keterampilan membuka pelajaran sebesar $61 \%$ (cukup), keterampilan bertanya sebesar 56\% (kurang), keterampilan mengadakan variasi sebesar 53\% (kurang sekali), dan menutup pelajaran 44\% (kurang sekali). Kemudian berdasarkan hasil wawancara didapatkan bahwa sebagian besar keterampilan dasar mengajar guru kimia masih kurang. Selama proses pembelajaran guru masih kurang dalam menerapkan keterampilan dasar mengajar. Hasil penelitian ini digunakan sebagai masukkan peran MGMP MIPA guna mengevaluasi kualitas guru yang berada di MAN Kota Tegal.

Penelitian lainnya yang mendukung hasil penelitian ini yaitu Mulyatun (2014) yang menunjukkan bahwa keterampilan dasar mengajar mahasiswa diamati dan dianalisis pada pelaksanaan Praktik Pengalaman Lapangan meliputi (1) Keterampilan bertanya, (2) Keterampilan memberi penguatan, (3) Keterampilan mengadakan variasi, (4) Keterampilan menjelaskan, (5) Keterampilan membuka dan menutup pelajaran, (6) Keterampilan membimbing diskusi kelompok kecil, (7) Keterampilan mengelola kelas, (8) Keterampilan mengajar kelompok kecil dan perorangan. Delapan keterampilan dasar mengajar Mahasiswa Tadris Kimia pada pelaksanaan PPL secara keseluruhan adalah baik dangan persentase penilaian mencapai $69,59 \%$. Keterampilan dasar mengajar mahasiswa Tadris Kimia yang paling menonjol adalah ketrampilan memberi penguatan $(74,14 \%)$, sedangkan ketrampilan yang paling rendah adalah keterampilan mengadakan variasi $(64,86 \%)$.

Selanjutnya temuan Harsa (2017) yang menyimpulkan secara keseluruhan, pengelolaan pembelajaran yang dilakukan oleh guru sudah baik, sebab dari 16 aspek yang dinilai hanya dua aspek saja yang tidak terpenuhi. Respon siswa terhadap pembelajaran dan perangkat menunjukkan respon positif. Pertanyaan (1), (3), dan (5), respon positif melebihi $70 \%$ yang menunjukkan minat dan semangat belajar siswa yang cukup tinggi. Hal tersebut menjadi penguatan bahwa pengelolaan pembelajaran yang baik oleh guru akan berdampak baik bagi siswa.

Selain itu, didukung pula oleh Ahmadiansah (2016) yang menyimpulkan bahwa pengaruh motivasi kerja dan kepuasan kerja sangat penting dalam memengaruhi kinerja. Dari analisis data, terlihat bahwa pengaruh motivasi dan kepuasan kerja terhadap kinerja guru di SMK Muhammadiyah Salatiga signifikan dengan signifikansi 0,003<0,05. Nilai 6,378 dengan kontribusi efektif 20,7\%.

Proses pendidikan akan berjalan efektif dan efisien apabila guru memiliki kompetensi yang memadai. Namun apabila kita pahami kembali tentang isi yang terkandung dalam setiap jenis kompetensi, seperti yang telah banyak disampaikan oleh para ahli pendidikan untuk menjadi seorang guru yang berkompeten bukan sesuatu yang mudah. Selain dipengaruhi oleh kompetensi, kinerja guru juga dipengaruhi oleh keterampilan yang dimilikinya. Begitupun dengan penyediaan fasilitas yang mendukung peningkatan kinerja guru menjadi tanggung jawab kepala sekolah. Untuk mewujudkan dan meningkatkan kompetensi guru dari segi keterampilan mengajar diperlukan usaha yang sungguh-sungguh baik yang berasal dari guru itu sendiri, kepala sekolah, pengawas maupun dari pemerintah.

\section{Pengaruh Motivasi Kerja terhadap Kinerja Guru}

Berdasarkan hasil penelitian memperlihatkan bahwa secara persial pengaruh keterampilan mengajar terhadap kinerja guru di SMP Negeri 3 Prabumulih. Hasil regresi yang didapat pada Tabel 4.10 dijelaskan bahwa jika nilai perolehan motivasi kerja $\left(\mathrm{X}_{2}\right)$ 
meningkat 1 unit skor, maka Kinerja Guru (Y) akan meningkat sebesar 0,380, dengan ketentuan nilai keterampilan mengajar $\left(X_{1}\right)$ nilainya 0 . Mengenai ada tidaknya pengaruh yang signifikan, dapat dilihat pada Tabel 4.9 dengan nilai $t_{\text {hitung }}$ variabel motivasi kerja sebesar 2,040 dengan tingkat signifikan 0,048 $(p<0,05)$, maka menolak Ho. Hal ini menunjukkan ada pengaruh yang signifikan motivasi kerja $\left(\mathrm{X}_{2}\right)$ terhadap Kinerja Guru $(\mathrm{Y})$. Ini menunjukkan bahwa motivasi kerja $\left(\mathrm{X}_{2}\right)$ berpengaruh terhadap Kinerja Guru $(\mathrm{Y})$.

Hal ini sejalan dengan hasil penelitian Rahayu (2014) menyimpulkan hasil penelitiannya menunjukkan bahwa persamaan garis regresi linier berganda yaitu $Y=0,182$ $+0,283+e ; Y$ (kinerja guru), X1 (motivasi), X2 (kepuasan kerja). Hasil tersebut menunjukkan bahwa ada pengaruh antara motivasi dan kepuasan kerja terhadap kinerja guru di SMP Negeri 5 Magelang. Output SPSS pengaruh X1 terhadap Y sebesar 0,643 dengan nilai hubungan parsial sebesar $12,1 \%$ pada taraf signifikansi 0,035 , sedangkan $\mathrm{X} 2$ terhadap $Y$ sebesar 0,178 dengan hubungan parsial sebesar $17,8 \%$ pada taraf signifikansi 0,011. Jadi semakin baik motivasi dan kepuasan kerja maka semakin baik pula kinerja guru.

Selanjutnya penelitian Ahmadiansah (2016) menyimpulkan hasil penelitiannya bahwa pengaruh motivasi kerja dan kepuasan kerja sangat penting dalam memengaruhi kinerja. Dari analisis data, terlihat bahwa pengaruh motivasi dan kepuasan kerja terhadap kinerja guru di SMKMuhammadiyah Salatiga signifikan dengan signifikansi 0,003<0,05. Nilai 6,378 dengan kontribusi efektif 20,7\%. Titin Ardiana (2017) menyimpulkan hasil penelitiannya bahwa motivasi kerja berpengaruh positif terhadap kinerja guru akutansi dengan kontribusi sebesar $80,6 \%$, selebihnya 19,4\% kinerja guru akutansi ditentukan oleh faktor-faktor lain.

Penelitian Pradika (2016) menyimpulkan penelitiannya bahwa kepuasan kerja berpengaruh positif dan signifikan terhadap kinerja guru honorer sekolah dasar seKecamatan Jogonalan dengan koefisien determinasi sebesar $51,4 \%$. Hasil analisis regresi berganda menunjukkan kepuasan kerja dan motivasi kerja secara simultan berpengaruh positif dan signifikan terhadap kinerja guru honorer sekolah dasar se kecamatan Jogonalan dengan koefisien determinasi sebesar $51,4 \%$.

Khairunnisa (2015) menyimpulkan hasil penelitiannya bahwa motivasi berprestasi dan kepuasan kerja mempunyai pengaruh yang tinggi terhadap kinerja guru SDN di Kecamatan Banjarmasin Tengah, yakni: (1) pengaruh motivasi berprestasi terhadap kinerja (15,1\%); (2) pengaruh kepuasan kerjaterhadap kinerja guru (15,8\%); dan (3) pengaruh motivasi berprestasi dan kepuasan kerja terhadap kinerja guru (20,5\%).

Burhan dkk (2018) menyimpulkan bahwa katagori motivasi kerja Kepala Sekolah Dasar di Kecamatan Jawai Selatan tinggi dengan distribusi frekwensi 49 responden dari 123 sampel atau 39,84\%. Ini berarti motivasi kerja kepala sekolah di daerah tersebut tinggi. Selanjunya motivasi kerja kepala sekolah berpengaruh secara signifikan terhadap disiplin kerja guru Sekolah Dasar di Kecamatan Jawai Selatan sebesar 39,84\% dengan tingkat signifikansi 0,000. Ini berarti bahwa motivasi kerja kepala sekolah dapat menentukan disiplin kerja guru. Meskipun ada faktor lain yang mempengaruhi tetapi tidak diteliti.

Penelitian Fatmasari (2014) menyimpulkan hipotesis pertama terdapat pengaruh yang positif motivasi kerja dengan prestasi belajar siswa ( $r \times 1 \mathrm{y}=0,670)$, kedua terdapat pengaruh yang positif antara kemampuan mengajar guru dengan prestasi belajar siswa ( $r \times 2 y=0,691)$, ketiga terdapat pengaruh yang positif antara motivasi kerja dan kemampuan mengajar terhadap prestasi belajar siswa $(r \times 1 \times 2=0,856)$. Hasil analisis secara bersamaan menunjukkan bahwa motivasi kerja dan kemampuan mengajar guru dapat mempengaruhi prestasi belajar siswa. Dari hasil pengujian variabel motivasi kerja guru yang mempunyai kemampuan mengajar tinggi mempunyai pengaruh yang signifikan terhadap prestasi belajar di gugus II Sekolah Dasar Kecamatan Kebayakan Kabupaten Aceh Tengah.

Hasil penelitian ini dapat dipahami karena jelas jika guru-guru memiliki motivasi kerja guru, maka mereka akan berupaya melaksanakan tugas dan tanggung jawabnya dengan sebaik-baiknya. Pada akhirnya, Kinerja Guru akan seiring dengan itu bahwa jika guru melaksanakan tugas dan tanggung jawabnya dengan sebaik-baiknya sesuai dengan kemampuannya berarti Kinerja Guru tersebut adalah kinerja terbaik yang ada dalam dirinya. 
Temuan penelitian menunjukkan bahwa motivasi kerja berpengaruh signifikan terhadap Kinerja Guru. Hal ini berarti semakin baik dan tinggi motivasi kerja yang dimiliki guru maka akan diikuti dengan meningkatan Kinerja Guru pada SMP Negeri 3 Prabumulih dan jika ada penurunan motivasi kerja guru akan memberikan pengaruh terhadap Kinerja Guru.

Bafadal (2009) menegaskan bahwa seseorang akan bekerja secara profesional bilamana orang tersebut memiliki kemampuan dan motivasi. Maksudnya adalah seseorang akan bekerja secara profesional bilamana seseorang memiliki kemampuan kerja yang tinggi dan motivasi untuk mengerjakan dengan sebaik-baiknya. Sebaliknya, seseorang tidak akan bekerja secara profesional bilamana hanya memenuhi salah satu persyaratan di atas. Jadi betapa pun tingginya kemampuan seseorang ia tidak akan bekerja secara profesional apabila tidak memiliki motivasi kerja yang tinggi. Dengan kata lain, aspek motivasi merupakan komponen paling penting dan berpengaruh dalam kinerja seseorang.

Menurut Sardiman (2014) motivasi berasal dari bahasa latin 'movere" yang berarti to move atau menggerakkan, diartikannya sebagai daya dorong seorang untuk melakukan sesuatu/pembelajaran sehingga menjadi aktif pada saat-saat tertentu, terutama apabila kebutuhan untuk mencapai tujuan sangat dirasakan atau dikehendaki.

Penjelasan dari hasil penelitian sebelumnya membuktikan bahwa motivasi kerja guru berpengaruh terhadap Kinerja Guru yang ditandai dengan tingginya nilai motivasi kerja guru dan Kinerja Guru. Namun, hal ini memiliki perbedaan dengan penelitian terdahulu berupa aspek yang dikaji dimana motivasi kerja guru dan Kinerja Guru menjadi variabel yang berbeda atau tidak diteliti dalam satu judul penelitian.

\section{Pengaruh Keterampilan Mengajar dan Motivasi Kerja Secara Bersama-Sama terhadap Kinerja Guru}

Berdasarkan hasil penelitian memperlihatkan bahwa pengaruh keterampilan mengajar dan motivasi kerja secara bersama-sama terhadap kinerja guru di SMP Negeri 3 Prabumulih. Hasil ini mendukung hipotesis yang diajukan di mana keterampilan mengajar dan motivasi kerja secara bersama-sama berpengaruh signifikan terhadap Kinerja Guru.

Dengan mengambil taraf signifikan sebesar 0,000 ( $p<0,05)$, maka Ho ditolak dan $\mathrm{Ha}$ diterima, hal ini dapat dilihat dari uji $F$ yang dilakukan di mana $F_{\text {hitung }}$ sebesar 22,024 $>F_{\text {tabel }}$ sebesar 3,22 . Artinya dapat disimpulkan bahwa ada pengaruh keterampilan mengajar dan motivasi kerja secara bersama-sama terhadap kinerja guru di SMP Negeri 3 Prabumulih dan terdapat hubungan yang positif antara variabel keterampilan mengajar dan variabel motivasi kerja dengan Kinerja Guru. Hal ini menunjukkan bahwa variabel keterampilan mengajar dan motivasi kerja secara bersama-sama mempengaruhi Kinerja Guru.

Kepala Sekolah perlu mengoptimalkan pembinaan kepada guru melalui pelaksanaan pembelajaran di sekolah dan lebih banyak lagi membenahi pemimpinan transformasional yang diterapkan di sekolah dalam upaya meningkatkan Kinerja Guru sehingga dapat terwujud kualitas pembelajaran dalam kerangka meningkatkan mutu pendidikan. Kepada para guru agar selalu meningkatkan Kinerja Guru di kelas dengan menjalin kerjasama yang baik dengan semua komponen yang ada di sekolah terutama kepala sekolah dalam penyelenggaraan pengawasan terhadap guru dalam pelaksanaan kepemimpinan transformasional.

Untuk meningkatkan mutu pendidikan nasional, yang harus mendapatkan perhatian yang khusus adalah pelaksanaan pembelajaran di kelas, karena di situlah terjadi interaksi perpindahan pengetahuan kepada peserta didik, untuk mendukung proses tersebut diperlukan adanya pelaksanaan supervisi akademik yang dapat menyentuh langsung kepada guru, dan dukungan dari kepemimpinan transformasional kepala sekolah yang dapat memotivasi dan membangkitkan semangat guru untuk menemukan dan melaksanakan pembaharuan dalam proses pembelajaran sehingga dapat terselenggaranya pembelajaran yang bermutu. 
Selain itu hasil penelitian ini sesuai dengan pendapat Biehler \& Snowman (2016) yang menyebutkan bahwa banyak faktor yang mempengaruhi guru giat dalam bekerja dan seringkali dijumpai bahwa guru yang giat bekerja dan tinggi motivasinya untuk berprestasi tiba-tiba tidak bersemangat sama sekali untuk melakukan sesuatu karena ditinggal mati suami atau istrinya (kebutuhan untuk dicintai tidak ini akan membuat kepala sekolah mengerti mengapa guru yang lapar, sakit atau mempunyai kondisi fisik tidak baik tidakmempunyai motivasi untuk bekerja. Guru akan lebih senang bekerja di dalam suasana yang nyaman dan menyenangkan. Guru yang merasa disenangi, diterima oleh teman sejawat atau dikagumi akan lebih berminat untuk bekerja dibanding dengan mereka yang terabaikan atau dikucilkan oleh teman sejawatnya. Keinginan guru untuk mengetahui dan memahami sesuatu tidak selalu sama.

Hasil penelitian ini membuktikan bahwa kemampuan kerja seorang guru dapat ditingkatkan jika ada faktor-faktor yang mempengaruhi, baik faktor internal maupun faktor eksternal dari seorang guru. Sehubungan hal ini ada teori pengharapan (Expectancy teory) dikemukakan oleh Vroom yang dikutip oleh Beck (2012) menyatakan bahwa kekuatan yang memotivasi seorang untuk bekerja giat dalam mengerjakan tugasnya tergantung dari hubungan timbal balik antara apa yang diinginkan dan dibutuhkan dari hasil pekerjaan tersebut.

Semua guru diangkat menjadi guru karena memiliki ijazah guru. Secara teoritis guru memiliki kompetensi untuk melaksanakan tugasnya. Namun, problem pendidikan semakin komplek untuk dihadari guru sendirian. Guru sebagai individu yang tidak sempurna, masih banyak yang tidak diketahui dan dikuasainya. Oleh sebab itu, guru membutuhkan bantuan orang lain yang dekat dengan dirinya untuk membantunya, dalam hal ini adalah kepala sekolah. Guru sebagai makhluk sosial, sehingga kompetensinya dipengaruhi oleh efektifitas keterampilan mengajar guru yang dilakukan di sekolah itu.

Motivasi kerja guru merupakan faktor internal guru, sedangkan kepemimpinan manajerial kepala sekolah dan supervisi kepala sekolah adalah faktor ekternal guru. Semakin tinggi motivasi kerja guru dan semakin bagus kepemimpinan manajerial serta supervisi kepala sekolah, maka akan memberi pengaruh yang lebih besar kepada Kinerja Guru karena motivasi kerja guru dari guru dan kepemimpinan manajerial serta supervisi kepala sekolah merupakan tiga hal yang berbeda yang dapat saling melengkapi untuk meningkatkan kinerja mengajar guru. Jika ketiga faktor tersebut dapat dipakai secara bersama, maka akan diperoleh Kinerja Guru yang lebih tinggi.

Kinerja Guru dalam suatu kegiatan belajar mengajar ada target bahan ajar yang harus dicapai oleh setiap guru di sekolah, yang didasarkan pada kurikulum yang berlaku saat itu. Jumlah bahan ajar yang banyaknya terangkum dalam kurikulum yang seringkali tidak sepadan dengan porsi waktu yang tersedia pada hari efektif. Di sisi lain, semua guru dituntut untuk bisa mencapai target tersebut. Untuk itu, perlu adanya strategi Kinerja Guru yang dilaksanakan di sekolah.

Mengingat tugas dan peran seorang guru yang sangat besar dan merupakan unsur yang sangat penting dalam bidang pendidikan, maka seorang guru harus mampu menempatkan kedudukannya sebagai tenaga yang profesional, sesuai dengan tuntutan dari masyarakat yang semakin berkembang. Sebagai seorang pendidik, guru bertugas mengajar dan menanamkan nilai-nilai dan sikap kepada siswanya, untuk melaksanakan tugas tersebut seorang guru harus memiliki berbagai kompetensi dan kepribadian yang menari.

Mengajar merupakan aktivitas mentransfer ilmu pengetahuan yang dilakukan oleh seorang guru dan peserta didik selaku penerima ilmu pengetahuan tersebut. Untuk mencapai tujuan yang telah ditentukan, diperlukan adanya proses pembelajaran yang dilakukan oleh guru berlangsung secara efektif. Kinerja Guru dalam melaksanakan proses belajar mengajar dapat dilihat dari berbagai aspek sebagai berikut 1) proses, 2) karakteristik guru, dan 3) hasil. Proses belajar mengajar menyangkut perilaku guru yang dinilai berdasarkan standar penampilan, misalnya bagaimana guru membuat perencanaan, menyajikan serta mengevaluasi pembelajaran. Karakteristik guru berkaitan dengan intelegensi, kesopanan kefasihan berbahasa, kepribadian, kesehatan. Hasil yakni berupa 
tingkat perubahan perilaku siswa sesuai dengan tujuan yang telah ditentukan dalam proses belajar mengajar.

\section{SIMPULAN}

Berdasarkan hasil analisis data, maka dapat disimpulkan 1) Ada pengaruh keterampilan mengajar terhadap Kinerja Guru, artinya keterampilan mengajar guru dapat mempengaruhi Kinerja Guru. Besarnya pengaruh keterampilan mengajar terhadap Kinerja Guru adalah $37,3 \%$; 2) Ada pengaruh motivasi kerja guru terhadap Kinerja Guru, artinya motivasi kerja dapat mempengaruhi Kinerja Guru. Besarnya pengaruh supervisi akademik terhadap Kinerja Guru adalah 38,0\%; dan 3) Ada pengaruh keterampilan mengajar dan motivasi kerja secara bersama-sama terhadap Kinerja Guru. Dengan demikian keterampilan mengajar dan motivasi kerja dapat mempengaruhi Kinerja Guru. Keterampilan mengajar dan motivasi kerja mampu mempengaruhi Kinerja Guru dengan kontribusi 51,2\% sedangkan sisanya $48,8 \%$ dijelaskan oleh faktor-faktor yang tidak termasuk dalam penelitian ini.

\section{UCAPAN TERIMA KASIH}

Ucapan terima kasih diberikan kepada Kepala SMP Negeri 3 Prabumulih, Rektor Universitas PGRI Palembang, Direktur Pascasarjana Universitas PGRI Palembang dan Ketua Program Studi Magister Manajemen Pendidikan Universitas PGRI Palembang yang telah membantu dalam penyelesaian jurnal ini yang merupakan produk dari tesis. Kemudian terima kasih juga kepada teman-teman mahasiswa Pascasarjana Universitas PGRI Palembang dan semua pihak yang telah membantu penulisan dan penerbitan jurnal ini.

\section{DAFTAR PUSTAKA}

Ahmadiansah. (2016). Pengaruh Motivasi Kerja dan Kepuasan Kerja Terhadap Kinerja Guru di Sekolah Menengah Kejuruan (SMK) Muhammadiyah Kota Salatiga. Jurnal Manajemen dan Kewirausahaan, Vol. 4, No. 2, (2016).

Andriani, S., Kesumawati, N., \& Kristiawan, M. (2018). The Influence of the Transformational Leadership and Work Motivation on Teachers Performance. International Journal of Scientific \& Technology Research, 7(7).

Arifin, Ahmad Zainal. (2012). Perencanaan Pembelajaran (Dari Desain Sampai Implementasi). Yogyakarta: Pedagogia.

Bafadal. (2009). Manajemen Sumber daya Manusia. Jakarta: Bumi Aksara.

Beck T. D. (2012). Transformational Leadership: Exploring its Functionality (Dissertation). Universitatas-Buchbinderei Georg Konrad. Munich.

Biehler \& Snowman. (2016). Faktor yang Mempengaruhi Guru Giat. Jakarta: Rineka Cipta.

Budiman, A. (2016). Kapita Selekta Kuesioner: Pengetahuan dan Sikap dalam Penelitian Kesehatan. Jakarta: Salemba Medika.

Burhan, H., Uray Husna Asmara., \& Aswandi. (2018). Pengaruh Supervisi Akademik Dan Motivasi Kerja Kepala Sekolah Terhadap Disiplin Kerja Guru SD. Jurnal Manajemen Pendidikan Volume 2 No. 1 Tahun 2018.

Djamarah, S. B., \& Zain, A. (2010). Strategi Belajar Mengajar. Jakarta: Rineka Cipta.

Fatmasari. (2014). Pengaruh Motivasi Kerja dan Kemampuan Mengajar Guru Terhadap Prestasi Belajar Siswa Pada Gugus II Sekolah Dasar Kecamatan Kebayakan Kabupaten Aceh Tengah. Jurnal IImiah Didaktika, Vol. XIV No. 2, 426-441.

Fitria, H., Kristiawan, M., \& Rahmat, N. (2019). Upaya Meningkatkan Kompetensi Guru Melalui Pelatihan Penelitian Tindakan Kelas. ABDIMAS UNWAHAS, 4(1).

Habibie. (2017). Analisis Keterampilan Dasar Mengajar Guru Kimia Yang Mengikuti MGMP MIPA di MAN Kota Tegal. Jurnal Manajemen Pendidikan. Vol 2. No. 1 (2017).

Hamalik, O. (2015). Kurikulum dan Pembelajaran. Jakarta: Bumi Aksara.

Harsa (2017). Analisis Keterampilan Mengajar Guru Terhadap Pembelajaran Matematika di Kelas X SMK. Jurnal Manajemen Mutu Pendidikan, Vol 1 No 2.

Husain (2012). Penerapan Keterampilan Mengajar Guru Pendidikan Agama Islam Dalam Meningkatkan Prestasi Belajar Peserta Didik Pada SMP Negeri DI Kecamatan Tubbi 
Taramanu Kabupaten Polewali Mandar. Jurnal Manajemen Mutu Pendidikan, Vol 2 No 1.

Khairunnisa. (2015). Pengaruh Motivasi Berprestasi Dan Kepuasan Kerja Terhadap Kinerja Guru Sdn Di Kecamatan Banjarmasin Tengah. Jurnal Paradigma, Volume 10, Nomor 2.

Khasanah, U., Kristiawan, M., \& Tobari. (2019). The Implementation of Principals' Academic Supervision In Improving Teachers' Professionalism in the State Primary Schools. International Journal of Scientific \& Technology Research, 8(8).

Kristiawan, M. (2015). A Model of Educational Character in High School Al-Istiqamah Simpang Empat, West Pasaman, West Sumatera. Research Journal of Education, 1(2), 15-20.

Kristiawan, M. (2016). Telaah Revolusi Mental dan Pendidikan Karakter dalam Pembentukkan Sumber Daya Manusia Indonesia Yang Pandai dan Berakhlak Mulia. Ta'dib, 18(1), 13-25.

Kristiawan, M., Ahmad, S., Tobari, T., \& Suhono, S. (2017). Desain Pembelajaran SMA Plus Negeri 2 Banyuasin III Berbasis Karakter Di Era Masyarakat Ekonomi ASEAN. Jurnal lqra': Kajian IImu Pendidikan, 2(2), 403-432.

Kristiawan, M., Maryanti, N., \& Fitria, H. (2019). Membangun Karakter Peserta Didik Melalui Green School di SMK Negeri 2 Muara Enim. JMKSP (Jurnal Manajemen, Kepemimpinan, Dan Supervisi Pendidikan), 4(2), 210-217.

Kristiawan, M., \& Rahmat, N. (2018). Peningkatan Profesionalisme Guru Melalui Inovasi Pembelajaran. Jurnal Iqra': Kajian IImu Pendidikan, 3(2), 373-390.

Kristiawan, M., Suryanti, I., Muntazir, M., \& Ribuwati, A. (2018). Inovasi Pendidikan. Jawa Timur: Wade Group National Publishing.

Moedjiono. (2014). Belajar dan Pembelajaran. Jakarta: Rineka Cipta.

Mulyatun. (2014). Analisis Keterampilan Dasar Mengajar Mahasiswa Calon Guru Kimia (Studi Pada Praktik Pengalaman Lapangan Mahasiswa Tadris Kimia). Jurnal Administrasi Pendidikan Vol. XII No. 2.

Pradika. (2016). Pengaruh Kepuasan Kerja dan Motivasi Kerja Terhadap Kinerja Guru Honorer Sekolah Dasar (SD) di Kecamatan Jogonalan Kabupaten Klaten. Jurnal Unwidha.

Putra, S. R. (2013). Desain Evaluasi Belajar Berbasis Kinerja. Yogyakarta: Diva Press.

Rahayu. (2014). Pengaruh antara Motivasi dan Kepuasan Kerja Terhadap Kinerja Guru di SMP Negeri 5 Magelang. Jurnal Manajemen Pendidikan, Volume 2, Nomor 1.

Renata, R., Wardiah, D., \& Kristiawan, M. (2018). The Influence of Headmaster's Supervision and Achievement Motivation on Effective Teachers. International Journal of Scientific \& Technology Research, 7(4).

Resnawati, A., Kristiawan, M., \& Sari, A. P. (2020). SWOT Analysis of Teacher's Professional Competency. International Journal of Progressive Sciences and Technologies (IJPSAT), 20(1), 17-25.

Salwa., Kristiawan, M., \& Lian, B. (2019). The Effect of Academic Qualification, Work Experience and Work Motivation towards Primary School Principal Performance. International Journal of Scientific \& Technology Research, 8(8).

Sardiman, A. M. (2014). Interaksi dan Motivasi Belajar Mengajar. Jakarta: Rajawali Pers.

Syah, M. (2012). Psikologi Belajar. Jakarta: Raja Grafindo Persada.

Turmini., Kristiawan, M., \& Sari, A. P. (2020). The Influence of Education, Training, and Experience towards Teacher's Professionalism. Electronic Research Journal of Social Sciences and Humanities, 2(2), 102-110

Uno, H. B. (2013). Teori Motivasi dan Pengukurannya: Analisis di Bidang Pendidikan. Jakarta: Bumi Aksara. 